\section{Physico-Chemical Water Quality in Ghana: Prospects for Water Supply Technology Implementation}

A.I. Schäfer ${ }^{1}$, H.M.A. Rossiter ${ }^{1}$, P. A. Owusu ${ }^{2}$, B.S. Richards ${ }^{3}$, E. Awuah ${ }^{2}$

School of Engineering and Electronics, University of Edinburgh, Edinburgh,

EH9 3JL, United Kingdom, email: Andrea.Schaefer@ed.ac.uk

Department of Civil Engineering, Kwame Nkrumah University of Science and Technology, Kumasi, Ghana

${ }^{3}$ School of Engineering and Physical Sciences, Heriot-Watt University, Edinburgh, EH14 4AS, United Kingdom

Published in Desalination

$$
248 \text { (2009) 193-203 }
$$

During an extensive sampling trial in Ghana, a number of physico-chemical water quality problems have been identified. For example, $\mathrm{pH}$ values of the collected samples ranged from 3.69 to 8.88 while conductivity ranged from 10 to $45000 \mu \mathrm{S} / \mathrm{cm}$ and turbidity from 0 to $>542$ NTU. Many wate samples analysed breached the drinking water quality guidelines. High levels of heavy metals were found and also locations high in sulphate and nitrate. In some regions chemical contaminants such as fluoride occur naturally and result in a significant number of boreholes being capped. While such capping results in the protection of the population of exposure to such chemicals, it may increase the risk for microbiological safety if surface water sources are used.

Keywords: chemical contaminants, heavy metals, water quality, Ghana, boreholes

\section{Introduction}

Worldwide waterborne diseases are the cause of death and suffering of millions of people, especially children in developing countries. The World Health Organisation (WHO) [1] estimates that improving sanitation and hygiene could drastically reduce child mortality. Water is an integra part of achieving all of the UN Millennium Development Goals [2]. While immediate deaths are caused by waterborne diseases caused by pathogens, long term exposure to chemicals such as arsenic, fluoride, uranium, nitrate and boron may cause chronic illness, disability and death. Pathogen removal can be achieved by chemical or physical disinfection and chemical contaminants require advanced treatment such as adsorption or filtration.

This study focuses on Ghana. The majority of the Ghana's population (58\%) live in rural areas. Many of these people live without the national infrastructure such as electricity grid and water services [3] and $66 \%$ of these people rely on surface water as a drinking water source, exposing them to waterborne diseases, such as diarrhoea, guinea worm and schistosomiasis [4, 5]. Unsafe water is a major cause of illness in the country, where one in ten children dies before the age of five [4]. The supply of clean water is limited by a lack of infrastructure, capacity and financial resources [6]. In an attempt to supply clean water boreholes are being drilled, which limits the construction for the presence of inorganic contaminants such as arsenic and fluoride [7-10]. Elevated manganese, arsenic, fluoride, lad and chromium in water sources in Ghana [11]. These may be naturally present in the groundwater, or may be caused by land-use and industry.

Gold mining is one of the main industries in Ghana accounting for $44 \%$ of Ghana's export earnings [12]. The large-scale extraction taking place in mainly Western and Ashanti region e.g. Bibiani and Obuasi, brings with it arsenic, mercury and sulphur contamination to water bodies, soil and even air pollution causing acid rain and degradation to the surrounding environment and impacts on human health [13-15]. Since legalisation of small-scale gold mining extraction in 1989, many people make a living through gold mining, employing extraction methods that inevitably release mercury into surrounding water sources $[12,16]$. Although the major gold mining has taken place mainly in the south, exploration is now also taking place in the north, e.g. in the Upper East. Ghana is also one of the worlds largest the exporters of manganese and is additionally exploring bauxite (Aluminium containing minerals) [12], in mainly in the south western part of the country [17, 18]. Iron and manganese have also been found in elevated concentrations in water in Ghana. Iron is not a health concern in itself, however elevated levels of both iron and manganese affect the taste and quality of drinking water, leading to colouration of cooking utensils and food. This has caused hundreds of wells to be abandoned in favour of surface waters likely contaminated with harmfu microorganisms $[5,11]$. Smedley found that many of the arsenic-rich stream waters had high

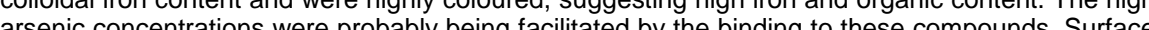
arsenic concentrations were probably being faciltated by he binding to these compounds. Surface Uranium content in Ghana is not well documented Smedley [11] measured uranium concentrations of up to $7 \mathrm{\mu g} / \mathrm{L}$ in ground water by Obuasi. Gold can be enriched with uranium. Eugster [19] found up to $321 \mathrm{mg} / \mathrm{kg}$ when they analysed gold samples from various locations in the world and it may thus be reased in coniunction with mining. Uranium has also been found in columbite-tantalite minerals mined in the Akim-Oda district in Ghana [20].

During the rainy season 2007 (July \& August; in the rainy season immediately before the major flooding throughout the region) a sampling field trial was condusted collecting 230 samples majo from borel $(66 \%$ of the samples) but also wells $(18 \%)$, surface water $(7 \%)$, piped $(5 \%)$ and from bortter (3.5\%) throughout Ghana. Extensive anas), of physico-chemical water quality and conducted and results are presented in this paper. The aim of this preliminary study was to determine likely hot spots of contamination for future treatment trials.

\section{Materials and Methods}

Sampling

Up to 20 samples were collected per day in $500 \mathrm{~mL}$ plastic bottles (see Figure 2). Bottles were transferred after initial analysis which was conducted as soon as practically possible, usually within 24 hours, into $25 \mathrm{~mL}$ sample vials. Where possible/relevant the name of the location, age of the borehole/well and handpump, funding agency, water charge, money collection system, maintenance arrangements and proximity of other water sources in the area were registered. A photograph of the pump and surrounding was taken to facilitate future identification of the location. It should be noted that based on the appearance it is often difficult to establish the nature of the water, i.e. bore or well or determine the depth of a bore. Surface waters (except wells) were sampled using gloves to avoid exposure to parasites. The sampling sites are indicated with circles on the map of Ghana in Figure 1.

\section{Analysis}

After collection all samples were filtered through a $0.45 \mu \mathrm{m}$ syringe filter (Sartorius Minisart, nonpyrogenic $\mathrm{CE}$ ) and stored in a $20 \mathrm{~mL}$ plastic vial. The remaining sample was analysed for $\mathrm{pH}$ conductivity, temperature (Multiline P4 multimeter, WTW) and turbidity (Turbidimeter TN-100, Eutech Instruments). Filtered samples were stored at ambient temperature and airlifted to the UK at the completion of the trial. Upon artival samples were kept at $4 \mathrm{C}$, separated and one portion acidified to $\mathrm{pH}<2$ (concentrated Aristar $\mathrm{HNO}_{3}$ ) for ICP-OES analysis whilst the other portion was kept untreated for IC analysis. Major cations of concentrations over $0.1 \mathrm{mg} / \mathrm{L}$ were detected by inductively coupled plasma-optical emission spectroscopy (ICP-OES) (Perkin Elmer Optima 5300 DV). Cations of concentrations down to $0.01 \mu \mathrm{g} / \mathrm{L}$ were analysed with inductively coupled plasma - mass spectroscopy (ICP-MS) (Agilent 7500ce). Calibrations were verified by a standard reference material (ICP Multi Element Standard Solution VI CertiPUR) and a reference water (SRM 1640). Anions were analysed using ion chromatography (DIONEX, Sunnyvale, CA, USA). Limits of detection (LOD) as well as relevant drinking water quality guidelines are tabulated in Table 1. 


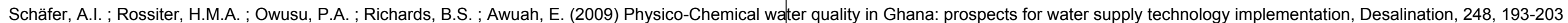
doi:10.1016/j.desal.2008.05.055

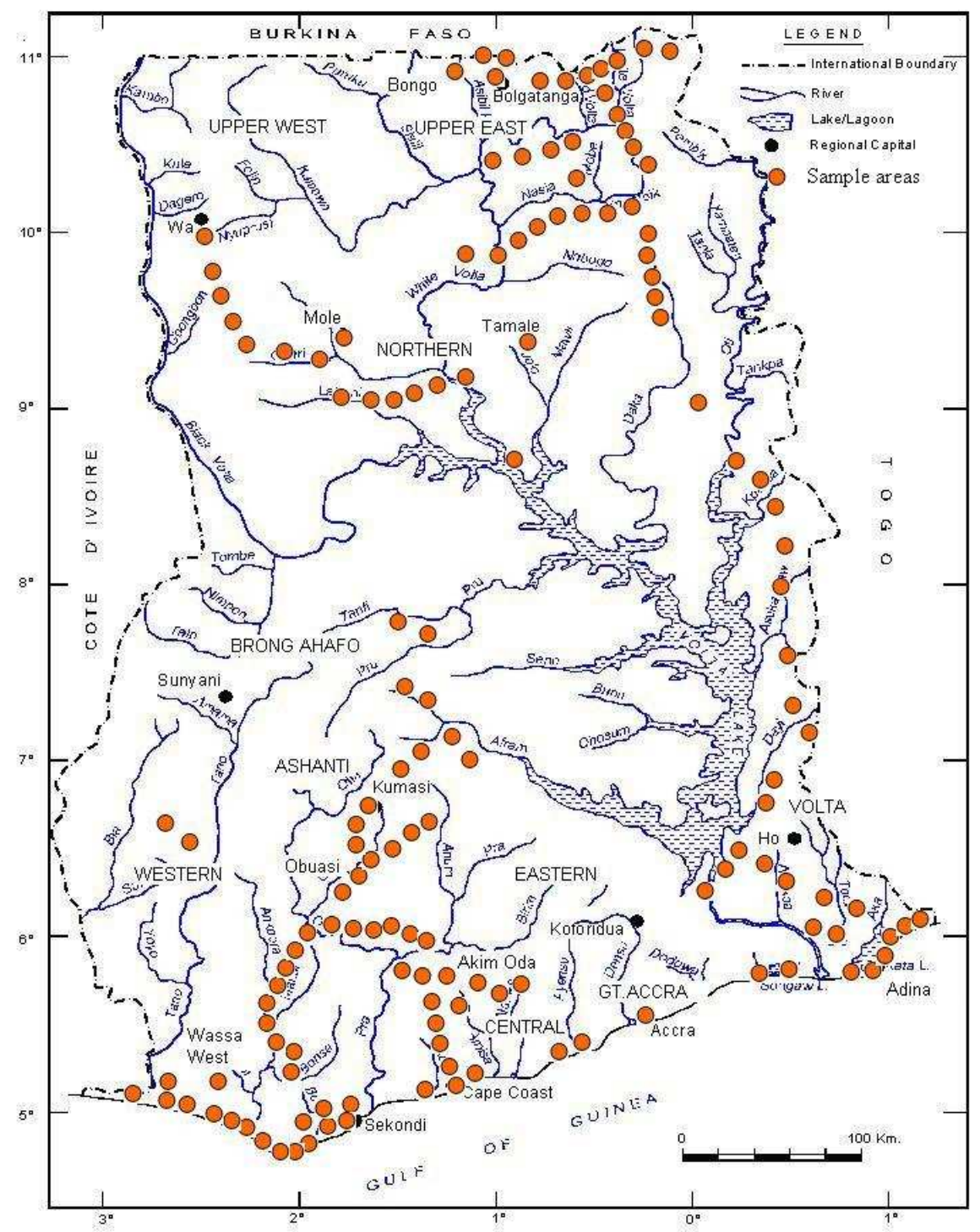

Table 1: Ions analysed as well as typical detection limits for each method and the WHO drinking water guideline for reference.

\begin{tabular}{|c|c|c|c|c|}
\hline ELEMENT & METHOD & UNIT & $\begin{array}{c}\text { LIMIT OF } \\
\text { DETECTION }\end{array}$ & $\begin{array}{c}\text { WHO GUIDELINE } \\
\text { VALUE }\end{array}$ \\
\hline Boron & ICP-MS & $\mu \mathrm{g} / \mathrm{L}$ & 2.551 & 500 \\
\hline Vanadium & ICP-MS & $\mu g / L$ & 0.011 & \\
\hline Manganese & ICP-MS & $\mu \mathrm{g} / \mathrm{L}$ & 0.057 & 400 \\
\hline Cobalt & ICP-MS & $\mu g / L$ & 0.051 & \\
\hline Nickel & ICP-MS & $\mu g / L$ & 0.054 & 20 \\
\hline Copper & ICP-MS & $\mu g / L$ & 0.173 & 2000 \\
\hline Zink & ICP-MS & $\mu \mathrm{g} / \mathrm{L}$ & 1.591 & $3000^{*}$ \\
\hline Arsenic & ICP-MS & $\mu \mathrm{g} / \mathrm{L}$ & 0.003 & 10 \\
\hline Selenium & ICP-MS & $\mu \mathrm{g} / \mathrm{L}$ & 0.306 & 10 \\
\hline Lead & ICP-MS & $\mu g / L$ & 0.006 & 10 \\
\hline Uranium & ICP-MS & $\mu g / L$ & 0.001 & 15 \\
\hline Chromium & ICP-MS & $\mu \mathrm{g} / \mathrm{L}$ & 0.068 & 50 \\
\hline Iron & ICP-MS & $\mu \mathrm{g} / \mathrm{L}$ & 0.001 & $300^{*}$ \\
\hline Cadmium & ICP-MS & $\mu \mathrm{g} / \mathrm{L}$ & 0.001 & 3 \\
\hline Mercury & ICP-MS & $\mu g / L$ & - & 1 \\
\hline Aluminium & ICP-OES & $\mathrm{mg} / \mathrm{L}$ & 0.02 & $0.2^{*}$ \\
\hline Magnesium & ICP-OES & $\mathrm{mg} / \mathrm{L}$ & 0.03 & \\
\hline Potassium & ICP-OES & $\mathrm{mg} / \mathrm{L}$ & 0.03 & \\
\hline Calcium & ICP-OES & $\mathrm{mg} / \mathrm{L}$ & 0.02 & \\
\hline Sulphur & ICP-OES & $\mathrm{mg} / \mathrm{L}$ & 0.1 & \\
\hline Barium & ICP-OES & $\mathrm{mg} / \mathrm{L}$ & 0.1 & 0.7 \\
\hline Fluoride & IC & $\mathrm{mg} / \mathrm{L}$ & 0.1 & 1.5 \\
\hline Bromide & IC & $\mathrm{mg} / \mathrm{L}$ & 0.2 & \\
\hline Chloride & IC & $\mathrm{mg} / \mathrm{L}$ & 0.2 & $250^{*}$ \\
\hline Sulphate & IC & $\mathrm{mg} / \mathrm{L}$ & 0.2 & $500^{*}$ \\
\hline Phosphate & IC & $\mathrm{mg} / \mathrm{L}$ & 0.1 & 3 \\
\hline Nitrate & IC & $\mathrm{mg} / \mathrm{L}$ & 0.2 & 50 \\
\hline
\end{tabular}

Figure 1: Map of Ghana with regions named and sampling sites indicated with circles. 


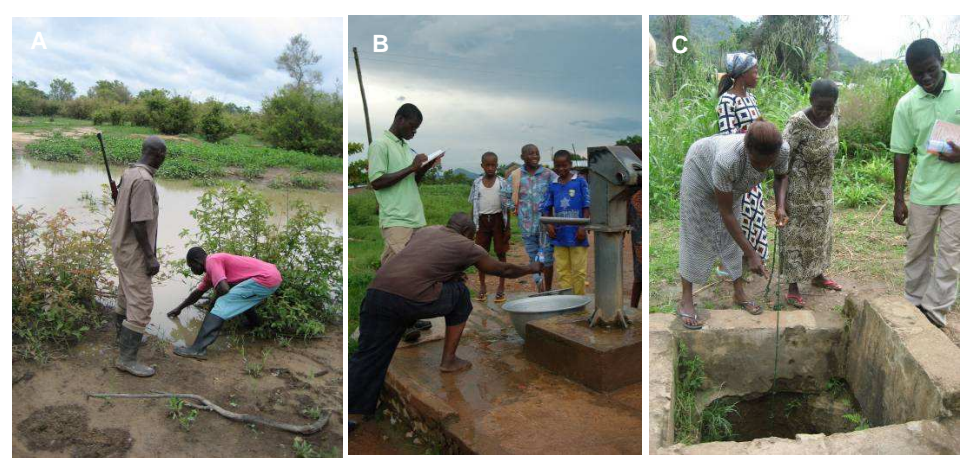

Figure 2. Water Sampling in Ghana (A) Surface Water, (B) Handpump on bore/well, (C) Well which was contaminated by surface run off.

\section{Results and Discussion}

Common lons: Aluminium, calcium, potassium, magnesium and total sulphur

The common ions aluminium (Al), calcium (Ca), potassium (K), magnesium $(\mathrm{Mg})$ and total sulphur (S) are reported in Figure 3. These compounds are not of great health concern and in consequence not regulated, although Al is a known neurotoxin as has been related by some studies to Alzheimer's disease [21-23] and even bone fragility [24]. Due to the use of Al in water processes but also taking concerns over neurotoxicity into account, a practicable guideline value is recommended by the WHO as maximum $0.2 \mathrm{mg} / \mathrm{L}$. Al concentrations in the samples ranged from the LOD to $68 \mathrm{mg} / \mathrm{L}$ with 199 samples ( $86 \%$ of samplo found in various localions in complained about the hardness of water, but stll use some boreholes for drinking. High levels were also foun to 30 . from LOD to $30 \mathrm{mgL}$,

Turbidity

Turbidity is a major concern of surface waters in particular during the rainy season. Values of up to 542 NTU (see Figure 4) were measured in surface waters such as the Black (420 NTU), Red (310 NTU) and White (542 \& 323 NTU) Volta Rivers, Oti River (345 NTU) and various surface ponds used to collect rainwater (422 \& 376 NTU). Various wells also showed high turbidities of up to 176 NTU. While most bore waters showed turbidities $<2$ NTU, some were as high as 266 NTU and such high values were often attributable to iron ( $85 \%$ ). The turbidity of the surface/well water did have such a values were often attibutable to iron (85\%). The turbidity of the surface/well water did have such a clear corch solids. Many of the high turbidity waters were difficult to filter, in particular those with an opaque white-yellow appearance (see Figure $5 A$ ). The turbidiy can most likely be attibuted to clays in helth che disinfection. $87 \%$ of the samples were above this guideline.

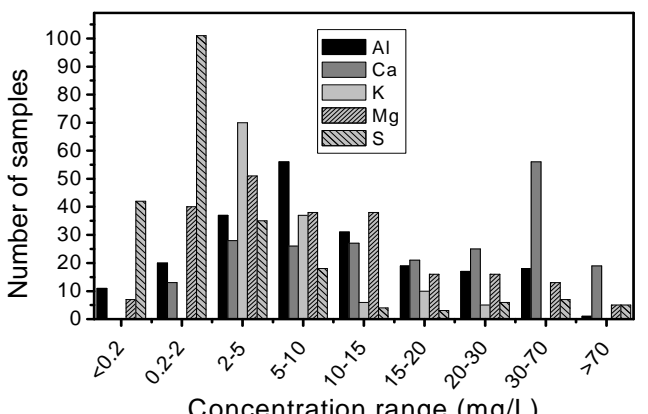

Concentration range $(\mathrm{mg} / \mathrm{L})$

Figure 3. Occurrence of major elements aluminium calcium, potassium, magnesium and sulphur. WHO guideline for $\mathrm{Al}$ is $0.2 \mathrm{mg} / \mathrm{L}$.

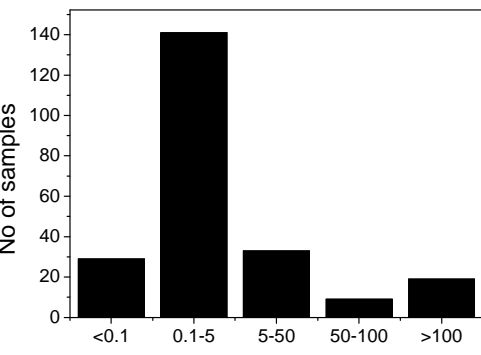

Turbidity range (NTU)

Figure 4. Distribution of turbidity found in samples. Recommended value for effective disinfection is 0.1 NTU.

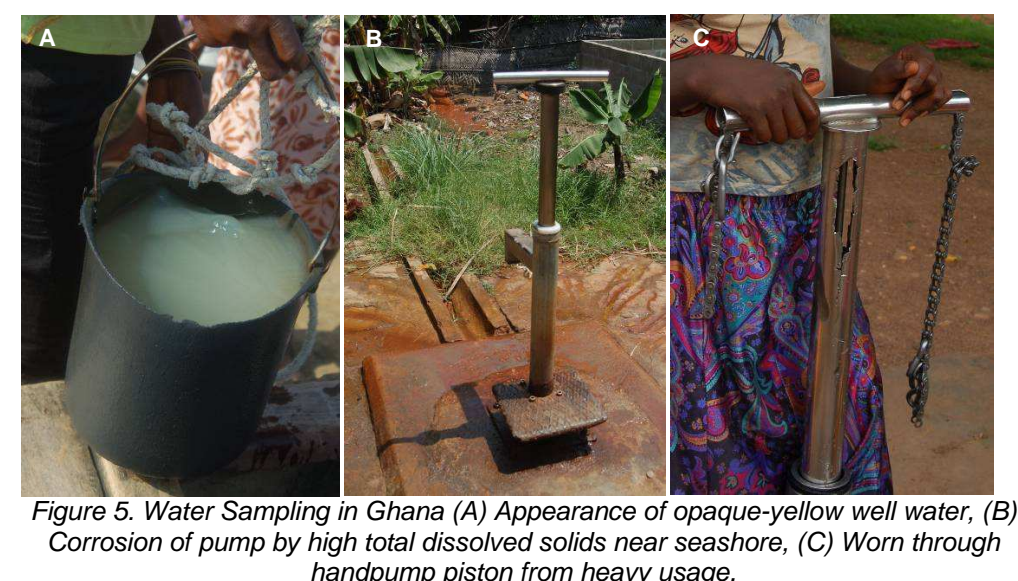

handpump piston from heavy usage.

Conductivity and total dissolved solids (TDS)

Electric conductivity is an indication of water salinity. TDS was calculated by adding the ions they note that a TDS above $1200 \mathrm{mg} / \mathrm{L}$ may be objection they note that a TDS above identified (5\% of smplos), mainy on the thentifed ( $5 \%$ of samples), the com, resulting in $\mathrm{mS} / \mathrm{cm}$, resulling in signilcant pup corosion (see Figure $5 \mathrm{~B}$ ). Oher handpumps fall due to over usage by shear We waiting for aid organizations to return to fix assets.

$\underline{p H \text { Value }}$

H values of the samples ranged from 3.7 to 8.9 (see Figure 7). A total of 115 samples (about $50 \%$ ) were outside the guideline values of 6.5-8.5. While the health impacts of such non-compliance 
are not clear, values of very low $\mathrm{pH}$ would make waters corrosive and hence place further strain on equipment. The highest $\mathrm{pH}$ was found in Lake Bosomtwi which has volcanic history. Generally forested soils would be expected to be more acidic [25] due to the increased rain fall (naturally acidic) [26], compared to the dry Savannah areas in the north. However, also very low $\mathrm{pH}$ values were found in the Northern Region.

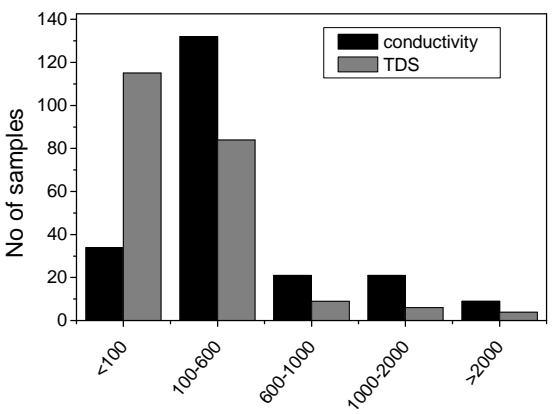

Range of Conductivity $(\mu \mathrm{S} / \mathrm{cm}) \&$ TDS $(\mathrm{mg} / \mathrm{L})$

Figure 6. Distribution of conductivity and TDS found in samples. Consumers may find water distasteful above a TDS of $1200 \mathrm{mg} / \mathrm{L}$

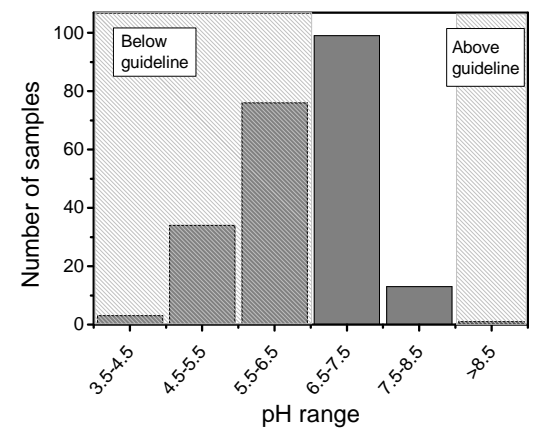

Figure 7. Distribution of $\mathrm{pH}$ values found in samples
Chloride, nitrate and sulphate

The ranges of chloride, sulphate and nitrate are displayed in Figure 8. Chloride $(\mathrm{Cl})$ and sulphate $\left(\mathrm{SO}_{4}{ }^{2}\right)$ do not have health based guidelines, but may cause concern due to taste if found at too high levels. The WHO, suggest that Cl levels over $250 \mathrm{mg} / \mathrm{L}$ may decrease the acceptability of the water due to taste, as well as leading to corrosion of metals. $\mathrm{Cl}$ concentrations in the samples ranged from $0.14 \mathrm{mg} / \mathrm{L}$ to about $20 \mathrm{~g} / \mathrm{L}$, of which $7 \%$ of the total samples were above the taste guideline.

Sulphate does not have a health-based guideline value, however the WHO recommends that concentrations higher than $500 \mathrm{mg} / \mathrm{L}$ should be reported to "the health authorities" due to problems to the gastrointestinal tract [1]. Sources can be both natural and industrial. The concentrations of $\mathrm{SO}_{4}^{2-}$ in the samples ranged from 0.14 to $2184 \mathrm{mg} / \mathrm{L}$, where the highest value for chloride and sulphate corresponded to the highest TDS sample. Apart from in Adina on the east coast, the highes $\mathrm{SO}_{4}^{2-}$ concentrations were found bore holes in the Northern Region. These results confirmed consumer complaints where the community actually used the well water rather than that from the bore due to the high sulphate levels.

Nitrate $\left(\mathrm{NO}_{3}^{-}\right)$is a contaminant that is regulated as it has significant health effects, especially on infants where nitrate is one of the causes of methaemoglobinaemia (or "blue-baby syndrome") [27, 28]. Low levels of nitrate are naturally present in water, however high levels result from anthropogenic sources such as sewage or fertilisers. Nitrate concentrations ranged from LOD to 508 $\mathrm{mg} / \mathrm{L}$ which is more than 10 times higher than the guideline value. Out of the total number of samples taken, $17 \%$ from both bores and well in various locations in the country and were above the guideline value.

Fluoride

Fluoride $(\mathrm{F})$ offers protection against dental caries at low concentrations but at higher levels causes serious problems such as dental and skeletal fluorosis. The levels of the samples taken across Ghana ranged from below the LOD to $19 \mathrm{mg} / \mathrm{L}$ (Figure 9), with $8 \%$ containing levels higher than the WHO guideline. As expected, most sources of high $\mathrm{F}$ levels were found in the Northern Region, in the Bongo district. Several water sources in this area had $F$ levels over the guideline value, both wells and boreholes. The people there suffer visibly from teeth problems, and a number of organisations are trying to find a solution to the high F levels -especially as many boreholes are simply capped if the F levels are found to be too high [29]. However, high F levels were also found scattered in different locations of the country, such as just north of Obuasi, Mole National Park, Accra and some locations along the coast. The highest $\mathrm{F}$ level $(19 \mathrm{mg} / \mathrm{L})$ was found in a borehole in Adina on the coast of the Volta Region. Extremely high levels were found in the same sample also of other elements such as $\mathrm{Al}, \mathrm{Ca}, \mathrm{Mg}, \mathrm{S}, \mathrm{B}, \mathrm{Mn}, \mathrm{Fe}, \mathrm{Cl}$ and $\mathrm{SO}_{4}{ }^{2-}$ indicate a serious contamination problem. The conductivity of this water was thus high: $48.3 \mathrm{mS} / \mathrm{cm}$ and the water surrounding the pump was of intense red colour (see Figure 5B). This water source was understandably not used for drinking as it had a sulphurous smell and a salty taste, but the community members use it for washing.

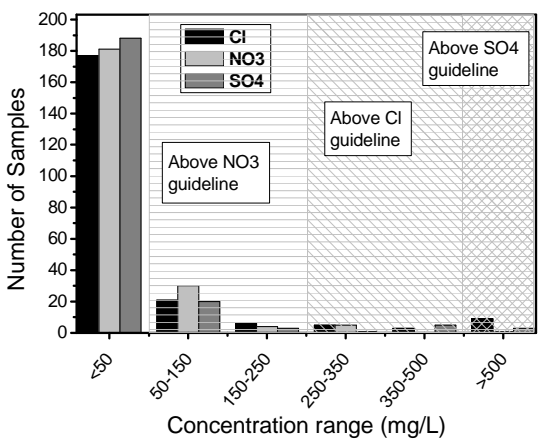

Figure 8. Distribution of chloride, nitrate and sulphate concentrations in samples

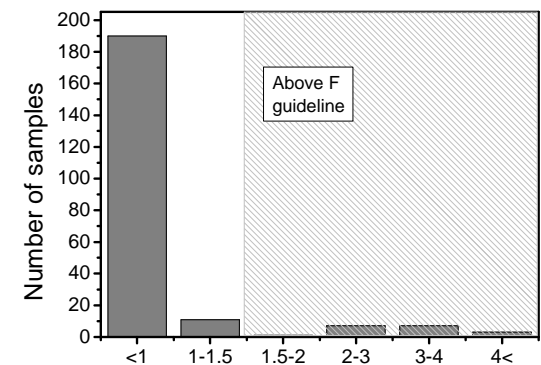

Fluoride Concentration range $(\mathrm{mg} / \mathrm{L})$

Figure 9. Distribution of Fluoride concentrations in sample. The guideline value is $1.5 \mathrm{mg} / \mathrm{L}$
Boron

Boron (B) is found naturally in the environment. Food rich in B include vegetables, fruit, legumes and nuts, but also in detergents and soap which may give rise to $B$ in the discharge of sewage treatment plants [30]. B is toxic to the male reproductive tract and the provisional WHO guideline value is set to $500 \mu \mathrm{g} / \mathrm{L}$. The concentrations measured ranged from below LOD to $2034 \mu \mathrm{g} / \mathrm{L}$ (Figure 10). About $3 \%$ of the total samples had concentrations above the guideline value, however, particularly high levels of $B$ were found in samples taken in the Northern Region of Ghana, especially in communities in the district of West Gonja (south-west of Tamale). The $\mathrm{pH}$ in these waters was slightly alkaline, about $\mathrm{pH}$ 8. Conductivity was between $800-1200 \mu \mathrm{S} / \mathrm{cm}$. One sample with very high levels of $B(960 \mu \mathrm{g} / \mathrm{L})$ also had high levels of $F(2.8 \mathrm{mg} / \mathrm{L})$.

\section{Iron and Manganese}

Iron ( $\mathrm{Fe})$ and manganese $(\mathrm{Mn})$ are naturally present through-out the environment and are generally perceived as safe, as often as taste will deter users from drinking water rich in these compounds. The concentration range of $\mathrm{Fe}$ varied widely from below LOD up to $82 \mathrm{mg} / \mathrm{L}$ (Figure 10). Despite not having a health based guideline for $\mathrm{Fe}$, a value of $0.3 \mathrm{mg} / \mathrm{L}$ is mentioned in the WHO drinking wate guidelines as a safe concentration, with the comment that taste will often be affected below this level. Out of the total samples, $6 \%$ were above this value. Levels above the guideline were found especially in rivers in e.g. in the Western Region, around the mining town Obuasi in the Ashant Region and in boreholes in some locations in the Northern Region. In the locations where such extremely high Fe levels were encountered, the consumers also noticed high colouration and some bores were no longer used for drinking purposes. Out of the samples containing high levels of $\mathrm{Fe}$ $85 \%$ were associated with high turbidity ( $>10$ NTU).

The $\mathrm{Mn}$ concentrations ranged from below LOD to a maximum of $5.7 \mathrm{mg} / \mathrm{L}$ (Figure 10). The WHO guideline value is set as $0.4 \mathrm{mg} / \mathrm{L}$ and $10 \%$ of the total samples were above this. Mn is an essential element but at high concentrations may have neurological effects [31]. It is often present in surface waters with low oxygen content. High levels can be due to industry or mining [32]. The highest levels were found in boreholes in for instance Akrofuom (south of Obuasi, 400-700 $\mu \mathrm{g} / \mathrm{L}$ ), odd locations in Northern Ghana (> $2000 \mu \mathrm{g} / \mathrm{L})$ and and along the coast $(\sim 1000-5000 \mu \mathrm{g} / \mathrm{L})$. Some bores were 
disused due to the taste. High levels (up to $1000 \mathrm{\mu g} / \mathrm{L}$ ) were also found in the Wassa West district around the town Bompieso. Despite high Mn levels this water was used for drinking. It was noted that some small scale mining was taking place close to the village, which might explain the high $\mathrm{Mn}$ levels found.

\section{Arsenic, Lead and Uranium}

Even though these elements are part of the earths crust they are not essential to humans. Arsenic (As) is well known for the catastrophic mass poisoning it has caused in e.g. Bangladesh through tube wells [33]. Arsenic has also been found in the mining areas in Ghana [29]. Confirming findings by prior studies, elevated levels of As were found in Obuasi municipality (with a history of mining activity). The concentrations across the country ranged from below LOD to $28 \mu \mathrm{g} / \mathrm{L}$ (Figure 11), with one sample containing as much as $169 \mu \mathrm{g} / \mathrm{L}$ (Bolgatanga municipality in northern Ghana). A few water samples $(1 \%)$ contained three times the set guideline value of $10 \mu \mathrm{g} / \mathrm{L}$. In a bore hole by Lake Bosomtwi high $\mathrm{Cl}$ and $\mathrm{NO}_{3}$ levels accompanied the As, which could indicate pollution from mining or agricultural activities. High levels of $\mathrm{Fe}$ and $\mathrm{Mn}$ were also found in this area, although it is interesting to note that the samples with high As do not necessarily contain high levels of $\mathrm{Fe} / \mathrm{Mn}$.

High levels $\mathrm{Pb}$ were also found. Overall the concentrations ranged from below the LOD up to $34 \mu \mathrm{g} / \mathrm{L}$ (Figure 11). $2 \%$ were found to be above the guideline value. The highest containing sample was taken from a borehole in the town Akrofuom. The $\mathrm{pH}$ of the water was very acidic $(\mathrm{pH} 3.69)$, which would lead to a higher dissolution of heavy metals. This town is located south of Obuasi and thus may be subject to contamination from the mining activities in the area. High levels of $\mathrm{Mn}$ and $\mathrm{NO}_{3}$ were also detected in this sample.

Uranium $(U)$ is not commonly analysed when testing drinking water quality, but due to its chemical toxicity (let alone its radioactivity), the guideline value is set to $15 \mu \mathrm{g} / \mathrm{L}$ and $1 \%$ of the samples contained $U$ over this level. These samples were found in a borehole in Odome in the Volta Region close to the border to Togo. This sample also measured high conductivity $(1886 \mu \mathrm{S} / \mathrm{cm})$ and worryingly contained $\mathrm{F}$ levels four times greater than the guideline value, $\mathrm{NO}_{3}$ values 10 times the guideline value as well as high $\mathrm{Cl}$. Another sample with high $\mathrm{U}$ was found in a well used for irrigation in Accra. This water had extremely high conductivity $(6.47 \mathrm{mS} / \mathrm{cm})$ and also contained very high $\mathrm{Cl}$ levels $(2232 \mathrm{mg} / \mathrm{L})$, high $\mathrm{F}(2 \mathrm{mg} / \mathrm{L})$. Apparently waste water from hotels and the airport residential area drain into this area and may thus cause the contamination measured, as well as well as possible intrusion of seawater. Extremely high levels of $U(257 \mu \mathrm{g} / \mathrm{L})$ were detected in a sample from a borehole in a community in the Assin North district. $U$ was also detected in a close by community, though below the limits of the drinking water guidelin. Generally $U$ was detected in samples from the Western and Central Region.

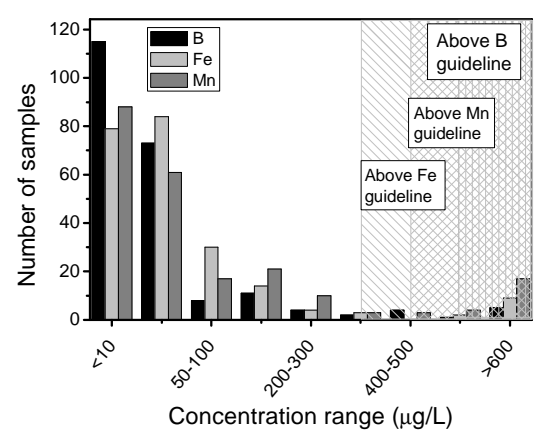

Figure 10. Boron, iron and manganese distribution of samples. Guideline values for $\mathrm{Fe}, \mathrm{Mn}$ and $\mathrm{B}$ are 300,400 and $500 \mu \mathrm{g} / \mathrm{L}$ respectively.

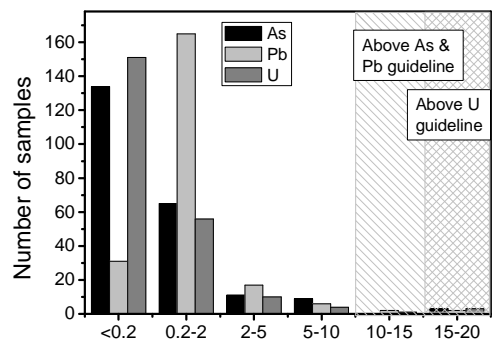

Concentration range $(\mu \mathrm{g} / \mathrm{L})$

Figure 11. Arsenic, lead and uranium distribution of samples. Guideline for As and $\mathrm{Pb}$ is $10 \mu \mathrm{g} / \mathrm{L}$ and for $U 15 \mu \mathrm{g} / \mathrm{L}$.
Other Elements

Other elements were also measured in the water, such as cadmium (Cd), barium (Ba), copper ( $\mathrm{Cu}$ ) nickel ( $\mathrm{Ni}$ ), selenium ( $\mathrm{Se}$ ) cobalt (Co), vanadium (V) and zinc ( $\mathrm{Zn}$ ). The levels found of these however were mainly below the WHO guideline values. Mercury $(\mathrm{Hg})$ analysis was attempted but unfortunately not successful, probably due to the high volatility of the metal requiring very efficient preservation [34].

\section{Conclusions}

A wide variety of inorganic contaminants have been identified in different locations in Ghana. The variation is probably due to natural variations in geology and also human mining and industria activities. High levels of $\mathrm{Al}$ were found to be quite widespread, along with $\mathrm{Fe}$ and $\mathrm{Mn}$, especially in the Volta Region. Presence of $\mathrm{F}$ was not only found in the most northern regions but also in different locations in the southern part of the country. Water sources from the mining areas in Central and Eastern Region showed high levels of $\mathrm{As}, \mathrm{Pb}$ and even some $\mathrm{U}$. High levels of $\mathrm{B}$ were found in the Northern Region, especially west of Tamale. Seawater intrusion seems to be a problem in the coastal areas, which were high in salts and $\mathrm{pH}$ values were found to be extreme in places. The coastal areas, which were high in salts and pH values were found to be extreme in places. The bores as well as the coordination of bore installations would be useful. This study has provided a first bores as well as the coordination of bore installations would be useful. This study has provided a first
overview of the chemical contamination issues of water sources from various locations throughout Ghana and will allow for more detailed investigations where necessary. It also provides a basis for evaluation of suitable water treatment technolion, where de-centralised systems seem a sensible evaluation of suitable water treatment technology, where de-centralised systems seem a sensible option. Areas with high levels of metals may require a relatively advanced treatment. A more detailed analysis of to collo contamination and also to investigate how the water sources are affected by the dry season.

\section{Acknowledgements}

A.I. Schäfer and B.S. Richards would like to extend thanks to UNESCO Scotland for project funding, the Royal Society and the Royal Academy of Engineering for travel support. A studentship from EPSRC and ESRC was provided for H.M.A. Rossiter. Mr. Samuel Ansere is thanked for his superb local guidance in Ghana as the driver of the team during the field trip in summer 2007 and KNUST for the provision of a vehicle. Tanya Peshkur and Dr Peter Anderson are thanked for assistance with IC analysis at Clarrc, and Dr Lorna Eades for assistance with ICP-MS (University of Edinburgh).

\section{References}

[1] WHO. Guidelines for Drinking Water Quality. 2004

2] UNESCO. Water a shared responsibility, the United Nations world water development report 2 . Paris, France and New York, USA: UNESCO and Berghahn Books, 2006.

[3] Yakubu $\mathrm{H}$. National Yor, USA. UNESCO and Berghahn Books, 2006

[4] Mohammed A-N. National Water Sector Assessment, Ghana In: WaterAid, editor. London: UK charity registration number 288701, 2006.

[5] Gyau-Boakye P, Dapaah-Siakwan S. Groundwater: Solution to Ghana's Rural Water Supply Industry? Accra: The Ghana Engineer, 1999.

[6] CIDA. Sustainab Development Strategy: 2004-2006 "Enabling Change". Quebeq: CIDA, 2004. [7] Pelig-Ba KB. Trace elements in groundwater from some crystalline rocks in the Upper Regions of Ghana. Water Air and Soil Pollution 1998; 103: 71-89.

[8] Pelig-Ba KB, Parker A, Price M. Trace element geochemistry from the Birrimian metasediments of the Northern Region of Ghana. Water Air and Soil Pollution 2004; 153: 69-93.

0]Perthern Region of Ghana. Water Air and Soll Pollution 2004, 153:69-93. [9] Pelig-Ba KB, Parker A, Price M. Elemental contamination of rainwater by airborne dust in Tamale Township area of the northern region of Ghana. Environmental Geochemistry and Health 2001; 23 333-346.

[10] Pelig-Ba KB, Biney CA, Antwi LA. Trace-Metal Concentrations in Borehole Waters from the Upper Regions and the Accra Plains of Ghana. Water Air and Soil Pollution 1991; 59: 333-345.

[11] Smedley PL. Arsenic in rural groundwater in Ghana. Journal of African Earth Sciences 1996; 22 $459-470$.

[12] Naylor R. Ghana An Oxfam Country Profile. Oxford: Oxfam, 2003. 


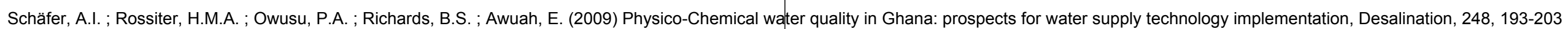
doi:10.1016/j.desal.2008.05.055

[13] Obiri S, Dodoo DK, Okai-Sam F, Essumang DK. Cancer health risk assessment of exposure to arsenic by workers of AngloGold Ashanti-Obuasi gold mine. Bulletin of Environmental Contamination and Toxicology 2006; 76: 195-201.

[14] Golow AA, Schlueter A, AmihereMensah S, Granson HLK, Tetteh MS. Distribution of arsenic and sulphate in the vicinity of Ashanti Goldmine at Obuasi, Ghana. Bulletin of Environmental Contamination and Toxicology 1996; 56: 703-710.

[15] AmonooNeizer EH, Nyamah D, Bakiamoh SB. Mercury and arsenic pollution in soil and biological samples around the mining town of Obuasi, Ghana. Water Air and Soil Pollution 1996; 91 363-373.

16] Ahmad K, Dampare SB, Adomako D, Opata NN, Quagraine RE. The use of neutron activation analysis in gold prospecting in small-scale mining in Ghana. Journal of Radioanalytical and Nuclear Chemistry 2004; 260: 653-658.

[17] BGS. Groundwater quality: Ghana. In: WaterAid, editor, 2001.

[18] Kesse GO. The mineral and rock resources of Ghana. Rotterdam, Netherlands: A.A.Balkema, 1985.

19] Eugster O, Niedermann S, Thalmann C, Frei R, Kramers J, Krahenbuhl U, Liu YZ, Hofmann B, Boer RH, Reimold WU, Bruno L. Noble gases, K, U, Th, and Pb in native gold. Journal of Geophysical Research-Solid Earth 1995; 100: 24677-24689.

20] Dampare SB, Nyarko BJB, Osae S, Akaho EHK, Asiedu DK, Serfor-Armah Y, Nude P. Simultaneous determination of tantalum, niobium, thorium and uranium in placer columbite-tantalite deposits from the Akim Oda District of Ghana by epithermal instrumental neutron activation analysis. Journal of Radioanalytical and Nuclear Chemistry 2005; 265: 53-59.

21] Flaten TP. Aluminium as a risk factor in Alzheimer's disease, with emphasis on drinking water. Brain Research Bulletin 2001; 55: 187-196.

[22] Martyn CN, Coggon DN, Inskip H, Lacey RF, Young WF. Aluminum concentrations in drinking water and risk of Alzheimer's disease. Epidemiology 1997; 8: 281-286.

[23] Rondeau V, Commenges D, Jacqmin-Gadda H, Dartigues JF. Relation between aluminum concentrations in drinking water and Alzheimer's disease: An 8-year follow-up study. American Journal of Epidemiology 2000; 152: 59-66.

[24] Mjoberg B, Hellquist E, Mallmin H, Lindh U. Aluminum, Alzheimer's disease and bone fragility. Acta Orthopaedica Scandinavica 1997; 68: 511-514.

25] Fisher RF, Binkley D, Pritchett WL. Ecology and management of forest soils: John Wiley and

[26] Spiro TG, Stigliani WM. Chemistry of the Environment. Upper Saddle River, New Jersey: Prentice Hall, 1996.

[27] Manassaram DM, Backer LC, Moll DM. A review of nitrates in drinking water: Maternal exposure and adverse reproductive and developmental outcomes. Environmental Health Perspectives 2006; 114: 320-327.

[28] Fewtrell L. Drinking-water nitrate, methemoglobinemia, and global burden of disease: A

[29] Smedley PL, Nkotagu H, Pelig-Ba KB, MacDonald AM, Tyler-Whittle R, Whitehead EJ, Kinniburgh DG. Fluoride in groundwater from high-fluoride areas of Ghana and Tanzania 'Minimising fluoride in drinking water in problem aquifers' R8033. Phase I Final Report. In: Survey BG, editor. Keyworth, Nottingham: British Geological Survey 2002. p.1-72.

[30] Williams M, Mumtaz M, Fay M, Scinicariello F, Jenkins K, Lumpkin M, Chappell L, McClure PR.

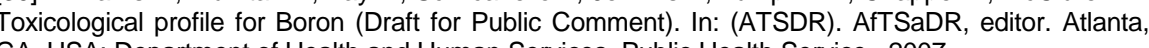
GA, USA. Departic

[31] Santos-Burgoa C, Rios C, Mercado LA, Arechiga-Serrano R, Cano-Valle F, Eden-Wynter RA Texcalac-Sangrador JL, Villa-Barragan $J P$, Rodriguez-Agudelo $Y$, Montes $S$. Exposure to Manganese: Health Effects on the General Population, a Pilot Study in Central Mexico. Environmental Research 2001; 85: 90-104.

istry. USA: CRC Press LLC, Lewis Publishers, 2000.

[33] Bissen M, Frimmel FH. Arsenic - a review. - Part 1: Occurrence, toxicity, speciation, mobility. Acta Hydrochimica Et Hydrobiologica 2003; 31: 9-18.

[34] Clesceri LC, Greenberg AE, Eaton AD. Standard methods for the examination of water and wastewater Washington: American Public Health Association, American Water Works Association Water Environment Federation, 1998. 